Available online at: https://proceeding.researchsynergypress.com/index.php/rsfconfereceseries1 RSF Conference Series: Business, Management and Social Sciences ISSN XXXX-XXXX (Online) | XXXX-XXXX (Print)

Volume 1 Number 2 (2021): 36-45

\title{
Social Medias' Effect on Intramuros' Tourism Growth as Perceived by National Capital Region Tourists
}

\author{
Rovena I. Dellova1, Paul Arndrei A. De Guzman², Miyara Shane R. De Jesus³, Hanna \\ Gocela4, Krista Joy Palmario5, Ryan Rey Aron6 \\ 1,2,3,4,5,6 College of International Tourism and Hospitality Management, Lyceum of the Philippines \\ University, Philippines
}

\begin{abstract}
Intramuros, also known as the "Walled City," is one of the Philippines' prides and a top tourist spot in Manila. If marketed well, more people will go down memory lane and learn about this must-see destination. One will venture into its culture and learn the history within the walls. To make use of this advantage, a platform is effective. Thus, social media impact is seen nowadays as an effective way to create an impact in the tourism industry. This study aims to explore how social media affected the tourism growth in Intramuros as perceived by tourists from National Capital Region. This descriptive study utilized snowball sampling resulting in 400 respondents from the National Capital Region, aged 18 and above, who visited Intramuros. The findings revealed that social media has a significant part in Intramuros' tourism growth. Thus, social media serves as a popular platform among visitors to research trips and share their travel's most significant memories. Reviews and Feedback help determine the needed improvement of Intramuros, and social media serves as a cost-effective way to reach target audiences. The walled city's cultural, historical, and religious benefits are some of the factors that influence the tourist to visit Intramuros.

Keywords: Tourism Growth, Social Media, Intramuros, Factors, Advancement
\end{abstract}

\section{INTRODUCTION}

Through the years, Social media has been a part of day-to-day life and transformed the way tourists make decisions. It has become a powerful tool in attracting potential visitors to any country who preferred tourist destinations. In addition, it has influenced the rapid adoption of technologies, thus, made them more accessible and convenient. Given the list of amazing scenic spots to visit in the Philippines, Intramuros in Manila has been the top pick as one of the notable tourist spots which have many historical sites.

Because of the advancement of technology in disseminating information, social media has been a very meaningful platform that gains tourism growth in Intramuros, Manila. According to the Department of Tourism (2020), visitors' dynamic rate in Intramuros, Manila, is continuously attracting tourists from 2014-2019. The rise of this rate was affected by social media platforms. Visitors keep growing because of the promotions and opening of new attractions. Moreover, this topic on Manila's Walled City, Intramuros, is viewed as a potential destination for promoting Philippine culture and legacy. This study sought to evaluate social media's effectiveness as a unique stage in developing tourism growth and how it has impacted the potential analytics on tourism since it encourages reviews on the travel experience of the tourist.

\section{LITERATURE REVIEW}

In an online world, seeing is believing. Hannah (2021) justified that we are now engaged in a visual world by navigating smartphones, social media sites, search engines, and platforms that 
RSF Conference Series: Business, Management and Social Sciences, Vol. 1 (2), 36-45

Social Medias' Effect on Intramuros' Tourism Growth as Perceived by National Capital Region Tourists

Rovena I. Dellova, Paul Arndrei A. De Guzman, Miyara Shane R. De Jesus, Hannah Gocela, Krista Joy Palmario, Ryan

Rey Aron

help one to decide and be connected. Tourists undertake a tour to unwind, recharge and enjoy an adventure in safe and enjoyable tourists spots (Garg 2013).

Garcia (2019) presented how people utilize social media as an instrument for delivering information. It combines the four subcategories of connecting, sharing, Exposure, and Feedback that speed up the platform's potential for advertising and promotion of destinations. Postma (2017) reiterated that the advancement in technology plays an important role in the substantial growth in tourism. There are components that will be affected, such as the social, economic, spatial and technological forces. Thus, ICT support the promotion and marketing strategies of tourism growth and help facilitate other developments online.

Almazan (2019) depicted that Intramuros is commonly considered the most visited by tourists with social media sites. Also, he added that social media's impact in 2019 on tourism growth in Intramuros was seen impressively. The Intramuros is home to a prosperous Spanish era and a historical landmark that depicts history's battles. The city starts to innovate to attract more tourists by placing lights. According to the Department of Tourism (2018), Intramuros draws 1 million locals and foreign tourists to celebrate Holy Week with such activities to support the Intramuros as a comprehensive religious location. Kim (2021) mentioned that marketing representatives use social media as a form of advertising to increase awareness of one's chosen brand.

In 2009, the UNESCO World Heritage Centre mentioned that the socio-cultural sights like traditions and festivities, indigenous peoples, monuments, and the sixteenth century's Walled Cities are advertised. Henderson (2011) cited that the Philippines has a diverse array of tourists attractions from its cultural and natural heritage, which is relaxing to the tourists.

Edera, E. (2019) affirmed that approximately 2.12 million sightseers went by the chronicled "Walled City," enlisting growth within the beginning of the semester of 2019. Secretary Puyat stated that the increment of visitors who have already visited the Intramuros for the past years had influenced tourism growth.

Hemsley (2018) mentioned that there are different ways on how to use social media, whether for good or bad, or both. It depends on how one perceives its purpose and who it might harm. Social media is an advantage for momentary connectedness, which means that there is an important computer-mediated publicness that allows communicating to reach the audience.

The effect of social media on the tourism industry, according to Mangan (2015), creates enormous opportunities. Users may analyze previews of their experience at a specific hotel, restaurant, or airline's passenger satisfaction. The Tourism Industry has been impacted by TripAdvisor, an application that offers travel insight, travel information, booking, and customer satisfaction.

Zhang (2021) argued that using the social medial can be categorized as political, which has something to do with the users intentionally seek for political concerns on Facebook, while the Nonpolitical describes that information seeks for maintaining a relationship or entertaining.

According to Roque (2015), the widespread use of online applications on digital networking has revolutionized tourist destinations. Per Uysal et al. (2016) mentioned that most travelers see social networking sites as a credible platform for having various data that can help them analyze and plan their travel.

Eyefortravel (2007) have shown in their studies that travelers are fond of social media' good reviews' more than negative ones. It implies that users turn to consumer-driven content to ensure 
RSF Conference Series: Business, Management and Social Sciences, Vol. 1 (2), 36-45

Social Medias' Effect on Intramuros' Tourism Growth as Perceived by National Capital Region Tourists

Rovena I. Dellova, Paul Arndrei A. De Guzman, Miyara Shane R. De Jesus, Hannah Gocela, Krista Joy Palmario, Ryan

Rey Aron

that the travel decision they are about to make is safe. In general, the number of reviews and comments on social media is relevant to travelers.

\section{RESEARCH METHOD}

The descriptive analysis approach was utilized in this study using snowball sampling, resulting in 400 respondents. The data were collected from those who visited Intramuros with age ranges from 18 years old and above. Since the study emphasizes the effect of social media on the tourism growth of Intramuros, the researchers used the quantitative method. The instrument used was a research-made survey questionnaire focused on the gathered study-related literature and studies. The survey questionnaire was validated and pre-tested before it was distributed. It was mandated that the respondents obtain valid answers regarding their perception of social media's effects on Intramuros' tourism growth.

\section{FINDINGS AND DISCUSSION}

Problem 1: What is the demographic profiles of the respondents in terms of:

Table 1Respondents' Age Category

\begin{tabular}{|l|l|l|}
\hline & FREQUENCY & PERCENTAGE \\
\hline $18-20$ years old & 75 & $18.8 \%$ \\
\hline $21-30$ years old & 238 & $59.5 \%$ \\
\hline $31-40$ years old & 54 & $13.5 \%$ \\
\hline $41-50$ years old & 24 & $6 \%$ \\
\hline 51 years old and above & 9 & $2.2 \%$ \\
\hline TOTAL & 400 & $100 \%$ \\
\hline
\end{tabular}

Respondents' Age Category has five groups, as shown in Table 1. The highest frequency belongs to the 21 to 30 category and is closely followed by the 18 to 21 category. This suggests that between 18 to 30 years old respondents are potential tourists who are eager to visit the beauty of the Walled City of Intramuros.

Table 2 Respondents' Gender Category

\begin{tabular}{|l|c|c|}
\hline & FREQUENCY & PERCENTAGE \\
\hline FEMALE & 234 & $58.5 \%$ \\
\hline MALE & 158 & $39.5 \%$ \\
\hline PREFER NOT TO SAY & 8 & $2.0 \%$ \\
\hline TOTAL & 400 & $100 \%$ \\
\hline
\end{tabular}


RSF Conference Series: Business, Management and Social Sciences, Vol. 1 (2), 36-45

Social Medias' Effect on Intramuros' Tourism Growth as Perceived by National Capital Region Tourists Rovena I. Dellova, Paul Arndrei A. De Guzman, Miyara Shane R. De Jesus, Hannah Gocela, Krista Joy Palmario, Ryan Rey Aron

Table 2 presents that the female category is 10 per cent higher than the male category. This means that many females are more interested in visiting the Intramuros and more interested in browsing social media compared to males.

Table 3. Respondents' Location Category

\begin{tabular}{|l|l|l|}
\hline & FREQUENCY & PERCENTAGE \\
\hline Caloocan & 28 & $7.0 \%$ \\
\hline Las Pinas & 11 & $2.7 \%$ \\
\hline Makati & 24 & $6.0 \%$ \\
\hline Malabon & 4 & $1.0 \%$ \\
\hline Mandaluyong & 2 & $0.5 \%$ \\
\hline Manila & 81 & $20.3 \%$ \\
\hline Marikina & 7 & $1.8 \%$ \\
\hline Muntinlupa & 6 & $1.5 \%$ \\
\hline Navotas & 6 & $1.5 \%$ \\
\hline Paranaque & 23 & $5.8 \%$ \\
\hline Pasay & 16 & $4.0 \%$ \\
\hline Pasig & 20 & $5.0 \%$ \\
\hline Pateros & 11 & $2.8 \%$ \\
\hline Quezon City & 69 & $17.3 \%$ \\
\hline San Juan & 3 & $0.7 \%$ \\
\hline Taguig & 74 & $18.5 \%$ \\
\hline Valenzuela & 15 & $3.8 \%$ \\
\hline TOTAL & 400 & $100 \%$ \\
\hline & & \\
\hline
\end{tabular}

This is an expected result where the numbers of respondents who visited Intramuros are residents from Manila. It was followed by Taguig, Quezon City, Caloocan, Makati and Parañaque. This implies that once a resident of Manila, people will never miss visiting and know more about the Walled City of Intramuros.

Table 4 Respondents' Religion

\begin{tabular}{|l|l|l|}
\hline & FREQUENCY & PERCENTAGE \\
\hline Agnostic & 1 & $0.3 \%$ \\
\hline Baptist & 2 & $0.5 \%$ \\
\hline Born Again & 21 & $5.3 \%$ \\
\hline Christian & 55 & $13.8 \%$ \\
\hline Roman Catholic & 297 & $74.3 \%$ \\
\hline Iglesia Ni Cristo & 10 & $2.5 \%$ \\
\hline Muslim & 4 & $1.0 \%$ \\
\hline Others & 10 & $2.5 \%$ \\
\hline TOTAL & 400 & $100 \%$ \\
\hline
\end{tabular}


Table 4 shows that most of the respondents' religions were Catholic, followed by Christian, Born Again, and Iglesia Ni Cristo. This study revealed that most of the Catholic respondents were interested in travelling in Intramuros since it has two amazing churches, namely, the Manila Cathedral and San Agustin Church.

Problem 2: How does social media affect the tourism growth of Intramuros in terms of: Table 5 Social Media's Effect on Connecting

\begin{tabular}{|c|c|c|c|}
\hline & MEAN & $\begin{array}{l}\text { STD. } \\
\text { DEVIATION }\end{array}$ & $\begin{array}{l}\text { VERBAL } \\
\text { INTERPRETATION }\end{array}$ \\
\hline $\begin{array}{l}\text { 1. Intramuros Administration } \\
\text { can utilize social media as } \\
\text { means for travel information. }\end{array}$ & 3.57 & 0.526 & STRONGLY AFFECTED \\
\hline 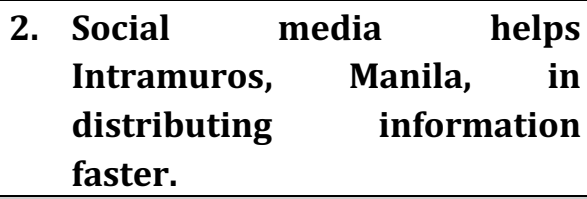 & 3.70 & 0.498 & STRONGLY AFFECTED \\
\hline $\begin{array}{l}\text { 3. Social media has a huge } \\
\text { influence on the tourism } \\
\text { growth of Intramuros. }\end{array}$ & 3.68 & 0.498 & STRONGLY AFFECTED \\
\hline $\begin{array}{l}\text { 4. Social media travel promotion } \\
\text { enticed me to visit the } \\
\text { Intramuros, Manila. }\end{array}$ & 3.58 & 0.575 & STRONGLY AFFECTED \\
\hline $\begin{array}{l}\text { 5. Social media is one of the well- } \\
\text { known ways to connect } \\
\text { information for potential } \\
\text { visitors. }\end{array}$ & 3.70 & 0.479 & STRONGLY AFFECTED \\
\hline WEIGHTED MEAN RESPONSE & 3.64 & 0.410 & STRONGLY AFFECTED \\
\hline
\end{tabular}

The Philippines has been considered to have one of the highest numbers of social network users across South East Asia. Thereby, Filipinos rely on social media as a meaningful tool and source of arranging tour packages. As shown in Table 5, the respondents' overall perception of social media connectivity is "strongly affected."

Table 6. Social Media's Effect on Sharing

\begin{tabular}{|l|l|l|l|}
\hline & MEAN & $\begin{array}{l}\text { STD. } \\
\text { DEVIATION }\end{array}$ & $\begin{array}{l}\text { VERBAL } \\
\text { INTERPRETATION }\end{array}$ \\
\hline $\begin{array}{l}\text { 1. } \\
\begin{array}{l}\text { Social media is a popular platform } \\
\text { among visitors in sharing personal } \\
\text { experiences, comments and } \\
\text { opinions. }\end{array}\end{array}$ & 3.75 & 0.452 & $\begin{array}{l}\text { STRONGLY } \\
\text { AFFECTED }\end{array}$ \\
\hline $\begin{array}{l}\text { 2. } \\
\text { It helps to reach a large number of } \\
\text { Visitors. }\end{array}$ & 3.70 & 0.502 & $\begin{array}{l}\text { STRONGLY } \\
\text { AFFECTED }\end{array}$ \\
\hline
\end{tabular}


RSF Conference Series: Business, Management and Social Sciences, Vol. 1 (2), 36-45

Social Medias' Effect on Intramuros' Tourism Growth as Perceived by National Capital Region Tourists Rovena I. Dellova, Paul Arndrei A. De Guzman, Miyara Shane R. De Jesus, Hannah Gocela, Krista Joy Palmario, Ryan

\begin{tabular}{|c|c|c|c|}
\hline \multicolumn{4}{|c|}{ Rey Aron } \\
\hline $\begin{array}{l}\text { 3. It opens opportunities to be } \\
\text { recognized both locally and } \\
\text { internationally. }\end{array}$ & 3.69 & 0.519 & $\begin{array}{l}\text { STRONGLY } \\
\text { AFFECTED }\end{array}$ \\
\hline $\begin{array}{l}\text { 4. Social media has become a word-of- } \\
\text { mouth tool of Intramuros. }\end{array}$ & 3.59 & 0.540 & $\begin{array}{l}\text { STRONGLY } \\
\text { AFFECTED }\end{array}$ \\
\hline $\begin{array}{l}\text { 5. Social media can spread false } \\
\text { information that can affect tourism } \\
\text { in Intramuros. }\end{array}$ & 3.54 & 0.569 & $\begin{array}{l}\text { STRONGLY } \\
\text { AFFECTED }\end{array}$ \\
\hline WEIGHTED MEAN RESPONSE & 3.65 & 0.389 & $\begin{array}{l}\text { STRONGLY } \\
\text { AFFECTED }\end{array}$ \\
\hline
\end{tabular}

Table 6 shows that Social media "strongly affected" the Visitors' perception in terms of sharing information on networking sites. Moreover, respondents also pointed out that "Social media is a popular platform among visitors in sharing personal experiences, comments, and opinions" interpreted as "strongly affected" with a highest average weighted mean. This result states that social media helps to expose Intramuros' charms through the personal sharing of the tourists.

Table 7. Social Media's Effect iin terms of Feedback

\begin{tabular}{|c|c|c|c|}
\hline & MEAN & $\begin{array}{l}\text { STD. } \\
\text { DEVIATION }\end{array}$ & VERBAL INTERPRETATION \\
\hline $\begin{array}{l}\text { 1. I become reliant on the information } \\
\text { posted on social media. }\end{array}$ & 3.31 & 0.632 & STRONGLY AFFECTED \\
\hline $\begin{array}{l}\text { 2. Feedbacks enable to determine } \\
\text { improvements for } \\
\text { Development. }\end{array}$ & 3.62 & 0.511 & STRONGLY AFFECTED \\
\hline $\begin{array}{l}\text { 3. Social media information can be } \\
\text { reliable. }\end{array}$ & 3.26 & 0.625 & STRONGLY AFFECTED \\
\hline $\begin{array}{l}\text { 4. Feedbacks posted on social media } \\
\text { affects potential visitors' decision- } \\
\text { making. }\end{array}$ & 3.58 & 0.519 & STRONGLY AFFECTED \\
\hline $\begin{array}{l}\text { 5. Rating and reviews posted on social } \\
\text { media help the tourism growth of } \\
\text { Intramuros. }\end{array}$ & 3.61 & 0.533 & STRONGLY AFFECTED \\
\hline WEIGHTED MEAN RESPONSE & 3.47 & 0.437 & STRONGLY AFFECTED \\
\hline
\end{tabular}

Table 7 depicts that social media "strongly affected" the decision-making motive of potential visitors. Moreover, respondents also identified that item 2, "Feedbacks enable to determine improvements for Tourism Development", is also a big help in the industries' success with highest average weighted mean. These findings depicted that tourists were encouraged to visit Intramuros through tourists' ratings, feedbacks and social media postings. 
Table 8. Social Media's Effect in terms of Exposure

\begin{tabular}{|l|l|l|l|}
\hline & MEAN & $\begin{array}{l}\text { STD. } \\
\text { DEVIATION }\end{array}$ & VERBAL INTERPRETATION \\
\hline $\begin{array}{l}\text { 1. } \\
\begin{array}{l}\text { Social media is a vital } \\
\text { promotional advertisement } \\
\text { since it interfaces everything. }\end{array}\end{array}$ & 3.62 & 0.541 & STRONGLY AFFECTED \\
\hline $\begin{array}{l}\text { 2. } \\
\text { Social media as a marketing } \\
\text { strategy acts as an instrument } \\
\text { for potential visitors. }\end{array}$ & 3.64 & 0.511 & STRONGLY AFFECTED \\
\hline 3. $\begin{array}{l}\text { Social media has become the } \\
\text { strategy to promote tourism in } \\
\text { Intramuros. }\end{array}$ & 3.65 & 0.528 & STRONGLY AFFECTED \\
\hline $\begin{array}{l}\text { 4. } \\
\text { Social media exposes different } \\
\text { experiences that a tourist may } \\
\text { encounter while visiting } \\
\text { Intramuros. }\end{array}$ & 3.62 & 0.541 & STRONGLY AFFECTED \\
\hline $\begin{array}{l}\text { 5. } \\
\text { Social media is one of the most } \\
\text { cost-effective ways to reach out } \\
\text { to targeted audiences. }\end{array}$ & 3.67 & 0.516 & STRONGLY AFFECTED \\
\hline WEIGHTED MEAN RESPONSE & 3.64 & 0.437 & STRONGLY AFFECTED \\
\hline
\end{tabular}

Table 8 concludees that the use of social media's in exposing the destination's attraction, facts, and trivia has a tremendous impact on tourism growth. It was shown that social media "strongly affected" the way Intramuros expose their history, culture, and Hispanic architecture online that generates potential. Also, respondents observed that the item "Social media is one of the most cost-effective ways to reach out to targeted audiences" has the highest average weighted mean. Given the social medias' effects on Exposure, this finding depicts that social media are acknowledged as an influencer on tourists travel choices.

Problem 3: Is there an effect on how social media influence the factors of tourism growth in Intramuros as perceived by NCR visitors in terms of:

Table 9. Social Media's Influence on Historical and Cultural Factor

\begin{tabular}{|l|l|l|l|}
\hline & $\begin{array}{l}\text { MEA } \\
\mathrm{N}\end{array}$ & $\begin{array}{l}\text { STD. } \\
\text { DEVIATION }\end{array}$ & $\begin{array}{l}\text { VERBAL } \\
\text { INTERPRETATION }\end{array}$ \\
\hline $\begin{array}{l}\text { 1. Intramuros is known as one of the tourist } \\
\text { destinations in the Philippines because of its } \\
\text { National Cultural Heritage Site. }\end{array}$ & 3.71 & 0.483 & GREAT EFFECT \\
\hline $\begin{array}{l}\text { 2. History of Walled City Intramuros helps in } \\
\text { gaining more knowledge in promoting } \\
\text { through social media means. }\end{array}$ & 3.59 & 0.546 & GREAT EFFECT \\
\hline $\begin{array}{l}\text { 3. Engaging activities inside Intramuros such } \\
\text { as visiting museums, festivals, bazaars, and }\end{array}$ & 3.67 & 0.492 & GREAT EFFECT \\
\hline
\end{tabular}


RSF Conference Series: Business, Management and Social Sciences, Vol. 1 (2), 36-45

Social Medias' Effect on Intramuros' Tourism Growth as Perceived by National Capital Region Tourists Rovena I. Dellova, Paul Arndrei A. De Guzman, Miyara Shane R. De Jesus, Hannah Gocela, Krista Joy Palmario, Ryan

Rey Aron

\begin{tabular}{|c|c|c|c|c|}
\hline \multicolumn{2}{|r|}{$\begin{array}{l}\text { tour guiding in historical places will boost } \\
\text { tourism growth. }\end{array}$} & & & \\
\hline 4. & $\begin{array}{l}\text { Visiting Intramuros will bring back the past } \\
\text { on how Dr. Jose Rizal plays a vital part in the } \\
\text { historical events of the Philippines, which } \\
\text { makes it more interesting for tourists to } \\
\text { visit. }\end{array}$ & 3.60 & 0.439 & GREAT EFFECT \\
\hline & $\begin{array}{l}\text { The historical activities and places inside } \\
\text { Intramuros encourage more visitors to visit } \\
\text { because it gives them a chance to see and } \\
\text { experience the culture of the past. }\end{array}$ & 3.65 & 0.503 & GREAT EFFECT \\
\hline & WEIGHTED MEAN RESPONSE & 3.64 & 0.414 & GREAT EFFECT \\
\hline
\end{tabular}

Table 9 expressed how social media can bring the heritage and cultural factors of Intramuros to life. It was shown that social media has a "great effect" on the perceptions of visitors. Analyzing the findings, it was discovered that item "Intramuros is known as one of the tourist destinations in the Philippines because of its National Cultural Heritage Site."

Table 10. Social Media's Influence on Religious Factor

\begin{tabular}{|l|l|l|l|}
\hline & MEAN & $\begin{array}{l}\text { STD. } \\
\text { DEVIATIO } \\
\text { N }\end{array}$ & $\begin{array}{l}\text { VERBAL } \\
\text { INTERPRETATION }\end{array}$ \\
\hline $\begin{array}{l}\text { 1. The seven (7) churches located in Intramuros } \\
\text { are factors for the tourism growth since it draws } \\
\text { attention to boost faith tourism to the visitors. }\end{array}$ & 7 & 0.553 & GREAT EFFECT \\
\hline $\begin{array}{l}\text { 2. The Roman Catholic population features a huge } \\
\text { effect on Tourism Growth since Intramuros is the } \\
\text { centre of rich Catholic Heritage. }\end{array}$ & 3.56 & 0.558 & GREAT EFFECT \\
\hline $\begin{array}{l}\text { 3. Due to the church's historical background, the } \\
\text { number of visitors and devotees, visiting } \\
\text { Intramuros for Visita Iglesia increases. }\end{array}$ & 3.54 & 0.595 & GREAT EFFECT \\
\hline $\begin{array}{l}\text { 4. The celebration of catholic events and practices } \\
\text { helps boost the tourism growth of Intramuros. }\end{array}$ & 3.53 & 0.579 & GREAT EFFECT \\
\hline $\begin{array}{l}\text { 5. The influence of Catholicism caused an effect on } \\
\text { Faith Tourism in boosting tourism growth in } \\
\text { Intramuros. }\end{array}$ & 3.48 & 0.600 & GREAT EFFECT \\
\hline \multicolumn{1}{|l|}{ WEIGHTED MEAN RESPONSE } & 3.54 & 0.491 & GREAT EFFECT \\
\hline
\end{tabular}

Intramuros was known for religious events and as an educational centre. It is well-known for pilgrims and other faith-based tourism activities. As shown above, Table 10 describes the role of Social media in influencing religious factors on the Tourism growth of Intramuros. This finding reveals how dominant the Roman Catholic population is in National Capital Region. The Spanish colony has a significant factor in this conclusion with an interpretation of "great effect". 
RSF Conference Series: Business, Management and Social Sciences, Vol. 1 (2), 36-45

Social Medias' Effect on Intramuros' Tourism Growth as Perceived by National Capital Region Tourists

Rovena I. Dellova, Paul Arndrei A. De Guzman, Miyara Shane R. De Jesus, Hannah Gocela, Krista Joy Palmario, Ryan

Rey Aron

Problem 4: Is there a significant relationship between social media and the tourism growth of Intramuros?

Table 11. Social Media's Relationship with Tourism Growth of Intramuros

\begin{tabular}{|l|l|l|l|}
\hline & MEAN & $\begin{array}{l}\text { STD. } \\
\text { DEVIATION }\end{array}$ & $\begin{array}{l}\text { VERBAL } \\
\text { INTERPRETATION }\end{array}$ \\
\hline $\begin{array}{l}\text { 1. } \\
\begin{array}{l}\text { Social media has a huge effect on } \\
\text { the tourism growth of } \\
\text { Intramuros. }\end{array}\end{array}$ & 3.67 & 0.503 & GREAT EFFECT \\
\hline $\begin{array}{l}\text { 2. } \\
\text { Social media is a crucial tool to } \\
\text { promote the tourism of } \\
\text { Intramuros. }\end{array}$ & 3.66 & 0.499 & GREAT EFFECT \\
\hline $\begin{array}{l}\text { 3. } \\
\text { media engage more in social } \\
\text { influences their travel decisions. }\end{array}$ & 3.67 & 0.516 & GREAT EFFECT \\
\hline $\begin{array}{l}\text { 4. } \\
\text { Social media is a significant factor } \\
\text { that affects the tourism growth of } \\
\text { Intramuros. }\end{array}$ & 3.68 & 0.509 & GREAT EFFECT \\
\hline WEIGHTED MEAN RESPONSE & 3.67 & 0.432 & GREAT EFFECT \\
\hline
\end{tabular}

Table 11 interprets that social media is vital to tourism growth. Hence, it acts as a marketing strategy to attract potential visitors that interpret a "great effect" on Intramuros tourism growth. The result of the findings pointed out that item "Social media is a significant factor that affects the tourism growth of Intramuros" has the highest weighted average means and is also interpreted as "great effect".

\section{CONCLUSION AND FURTHER RESEARCH}

With the penetration of social media in the Philippines, almost all Filipinos rely on the social media application as a meaningful platform to check on travel information. This study proves that it is an effective tool to encourage tourists to include Intramuros in their bucket list and witness the charm of historic Walled City.

Based on the result of the data gathered, most of the respondents were female, ages 21 to 30 , and from Manila. This implies that once a resident in Manila, people will never fail to visit Intramuros, same with how foreign tourists prioritize this as part of their itinerary.

Another significant finding is that the majority of the respondents are Catholic, which strengthens the overall result in analyzing the effect of social media on the tourism growth of Intramuros. Historically speaking, the Philippines is the third-largest Catholic population in the world. Filipinos stand out for their devotion and penitential rituals.

The effectiveness of Social Media on the tourism growth of Intramuros in terms of connecting revealed that Social Media is an essential tool for promoting tourism effectively. It helps to expose Intramuros' charms through the personal sharing of the tourists' travel tips and itineraries. They share their pictures, experiences, comments through their social media posting. 
RSF Conference Series: Business, Management and Social Sciences, Vol. 1 (2), 36-45

Social Medias' Effect on Intramuros' Tourism Growth as Perceived by National Capital Region Tourists

Rovena I. Dellova, Paul Arndrei A. De Guzman, Miyara Shane R. De Jesus, Hannah Gocela, Krista Joy Palmario, Ryan

Rey Aron

Overall, the study's findings show that social media's effect contributed to Walled City's tourism growth. It is evident that it acts as an effective marketing strategy to attract potential tourists that leads to the advancement of tourism. The use of social media for advertising has a massive impact on tourism development, specifically in Intramuros.

This study would benefit students and tourism-related industries such as the Department of Tourism and the Intramuros Administration in order to promote, develop the tourism activity and encourage everyone to witness the famous Intramuros in the Philippines.

\section{REFERENCES}

Almazan, F. (2020, January 26). 3.7M tourists visited Intramuros, The Manila Times

Department of Tourism-Philippines.

http://tourism.gov.ph/news_features/intramuros_draws.aspx\#

Edera, E. (2019). 2.12 million Tourists visited the Walled City of Intramuros. Manila Bulletin. https://mb.com.ph/2019/10/04/2-12-million-tourists-visited-walled-city-ofintramuros-in-1st-semester-of-2019/

Eyefortravel. (2007). Asia's Travel Industry Charges into 2007 / Travel Industry News \& Conferences - Reuters Events. https://www.reutersevents.com/travel/archive/asia\%E2\%80\%99stravel-industry-charges-2007

Hannah, M. "A Conspiracy of Data: QAnon, Social Media, and Information Visualization https://journals.sagepub.com/doi/full/10.1177/20563051211036064. 2021

Henderson, J., "Tourism Development and Politics in the Philippines", Tourismos: An International Multidisciplinary Journal of Tourism, Vol. 6, Number 2, Autumn 2011

http://www.chios.aegean.gr/tourism/VOLUME_6_No2_art09.pdf

Garcia, I. (2019) Social Media-Integration-Theory-Model I Social Media Today. https://www.socialmediatoday.com/content/social-media-integration-theory-model

Garg, A. (2013) "A Study of Tourist Perception Towards Travel Risk Factors in Tourist Decision Making" Asian Journal of Tourism and Hospitality https://ejournals.ph/article.php?id=1818

Hemsley, J. (2018) "Social Media for Social Good or Evil: An Introduction" https://journals.sagepub.com/doi/full/10.1177/2056305118786719

Kim, E. et al., (2021)“ Living in a Material World: Sponsored Instagram Posts and the Role of Materialism, Hedonic Enjoyment, Perceived Trust, and Need to Belong" https://journals.sagepub.com/doi/full/10.1177/20563051211038306.

Mangan, M. (2015, September 23). The Impact of Social Media on the Tourism Industry. Hospitality Net. https://www.hospitalitynet.org/news/4071855.html

Postma, A. (2017) "The Future of City Tourism" Journal of Tourism Futures ISSN:2055-5911 https://www.emerald.com/insight/content/doi/10.1108/JTF-09-2017-067/full/html

Roque (2015). Social Media as a Communication and Marketing Tool in Tourism: An Analysis of Online Activities", Anatolia, 27(1), 58-70. https://doi.org/10.1080/13032917.2015.1083209

UNESCO World Heritage Centre. (2019). Baroque Churches of the Philippines. Http://whc.unesco.org/en/list/677

Uysal, M. et al. (2016). Handbook of Tourism and Quality-of-Life Research: Enhancing the Lives of Tourists and Residents of Host Communities

Zhang, B. (2021) "How Does Facebook Use for Politics Motivate Unfriending and Muting" The Journal of Social Media in Society https://www.thejsms.org/index.php/JSMS/article/view/895/423 